\title{
TRANSCRIPTIONAL AND PHOSPHO-PROTEOMIC SCREENS REVEAL STEM CELL ACTIVATION OF INSULIN-RESISTANCE AND TRANSFORMATION PATHWAYS FOLLOWING A SINGLE MINIMALLY TOXIC EPISODE OF ROS
}

\author{
MOUZANNAR R. ${ }^{1}$, MCCAFFERTY J.2, BENEDETTO G. ${ }^{1}$, AND RICHARDSON C. *1 \\ 1UNC-Charlotte, Department of Biology and Bioinformatics Research Center, Charlotte, NC 28223 \\ UUNC-Charlotte, Department of Bioinformatics and Genomics, Charlotte, NC 28223 \\ ${ }^{*}$ Corresponding author. E-mail: UNC-Charlotte, 9201 University City Blvd. Woodward Bldg. Room 386B, Charlotte \\ NC 28223, phone: (704) 687-8683, FAX: (704) 687-3128, caricha2@uncc.edu
}

Received: January 6, 2011; Accepted: January 31, 2011

\section{RUNNING TITLE: STEM CELL RESPONSE TO MINIMALLY TOXIC ROS}

\begin{abstract}
Elevated reactive oxidative species (ROS) are cytotoxic, and chronic elevated levels of ROS have been implicated in multiple diseases as well as cellular transformation and tumor progression. However, the potential for a transient and minimally toxic episode of ROS exposure, or a minimal threshold dose of ROS, to initiate disease or cellular transformation is unclear. We examined both transcriptional and phospho-proteomic responses of murine embryonic stem (ES) cells to a single brief exposure of minimally toxic hydrogen peroxide $\left(\mathrm{H}_{2} \mathrm{O}_{2}\right)$. The cellular response was distinct from those induced by either an acute exposure to $\mathrm{H}_{2} \mathrm{O}_{2}$ or the topoisomerase II poison etoposide. Analysis of tumorigenesis-related transcripts revealed a significant up-regulation of oncogenes and down-regulation of tumor suppressors. Analysis of the phospho-proteomic response demonstrated insulinsignaling induction, including insulin receptor Y972 hypophosphorylation, similar to insulin-resistance mouse models and observed in diabetic patients. In addition, ES cells were more resistant to ROS than differentiated cells, and retained their transcriptional self-renewal signature, suggesting stem cells have a higher potential for ROS-mediated mutagenesis and proliferation in vivo. These results are a direct demonstration that even brief and non-toxic exposures to ROS may induce transduction of insulin resistance and transformation signaling in stem cells leading to diabetes and cancer.
\end{abstract}

Key words: reactive oxygen species, oxidative stress, DNA damage, stem cells, gene expression, microarray, proteomics, insulin, diabetes, cancer

\section{Introduction}

Reactive oxygen species (ROS) are produced by metabolizing molecular oxygen to produce hydroxyl free radicals $(\cdot \mathrm{OH})$, superoxide anions $\left(\mathrm{O}_{2} \cdot \cdot\right)$, singlet oxygens $\left({ }^{1} \mathrm{O}_{2}\right)$, and hydrogen peroxide $\left(\mathrm{H}_{2} \mathrm{O}_{2}\right)$. ROS are generated by endogenous reduction of oxygen, by the mitochondrial respiratory pathway, as well as by exogenous exposure to UV or environmental damaging agents [1]. Superoxides produced by NADPH oxidase activity are quickly dismutated by superoxide dismutases (SODs) to the more stable $\mathrm{H}_{2} \mathrm{O}_{2}$. ROS levels in cells are highly regulated. Increases in ROS above basal cellular concentrations lead to oxidative stress (OS) [2]. OS is thought to damage 20,000 bases per day per human cell and be one of the major causes of DNA damage and mutation $[3,4]$.

At submicromolar concentrations, ROS act as proliferation and growth signaling molecules. Elevated levels of ROS induced by mutations of metabolic enzyme genes, ischemia/reperfusion, chemotherapy, or chronic exposure to $10-100 \mu \mathrm{M}$ $\mathrm{H}_{2} \mathrm{O}_{2}$ induce multiple effects ranging from cell cycle arrest to death, depending on the cell type $[5,6]$. High levels of ROS have been implicated in human diseases including cancer, diabetes, cardiac disease, neurodegeneration, and aging $[4,7,8]$. In support of this, high levels of OS induced by metabolic enzyme deficiency are associated with head and neck cancers as well as child T-cell leukemia $[9,10]$. High concentrations of $\mathrm{H}_{2} \mathrm{O}_{2}(3 \mathrm{mM})$ can induce multiple insulin-like effects in rat adipose tissue including phosphorylation of the insulin receptor (INSR) $\square$ subunit at E80 and Y20 [11]. However, the potential for a transient and minimally toxic episode of ROS exposure or what minimal threshold dose of ROS to initiate disease or cellular transformation is unclear.

Upon differentiation of embryonic stem (ES) cells, superoxide production, cellular levels of intracellular ROS, and DNA damage levels increase. At the 
same time, expression of major antioxidant genes and genes involved in multiple DNA repair pathways is downregulated [12], and DNA repair by homologous recombination is reduced [13]. Thus, elevated ROS may promote tumorigenesis in more differentiated somatic cells indirectly through increased illegitimate repair of the ensuing DNA damage. It is not clear how susceptible stem cells are to a single brief exposure of ROS, particularly at minimally toxic doses not expected to induce apoptosis.

A significant body of literature exists on the transcriptional response of multiple cell types to high toxic or low chronic doses of ROS [14-23] but not the impact of a single minimally toxic ROS episode. In addition, the immediate coordination of both transcriptional and post-translational responses in response to ROS is not understood. In this study we measured the immediate cellular response of mouse ES cells to a single minimally toxic episode of hydrogen peroxide $\left(\mathrm{H}_{2} \mathrm{O}_{2}\right)$. The cellular response was distinct from those induced by either an acute exposure to $\mathrm{H}_{2} \mathrm{O}_{2}$ or by the topoisomerase II poison etoposide. Parallel examination of transcriptional profiles with the posttranslational modifications of a significant though limited number of signaling molecules demonstrated that a single minimally toxic exposure to ROS is sufficient to induce significant increases in oncogenic and metastatic pathways and specifically induce insulin signaling, similar to insulin-resistance mouse models and observed in diabetic patients. Despite the significant signaling changes induced by ROS, cells maintained their stem cell signatures suggesting a mechanism for maintenance, survival, and transformation in early stem cell pools.

\section{Results \\ Growth arrest, cytotoxicity, and DNA fragmentation}

ES cells were exposed to a minimally toxic $100 \square \mathrm{M}$ hydrogen peroxide $\left(\mathrm{H}_{2} \mathrm{O}_{2}\right)$ for $15 \mathrm{~min}$. Dose was chosen as $\mathrm{H}_{2} \mathrm{O}_{2}$ concentrations up to $50 \mu \mathrm{M}$ have been reported in human plasma and $100 \mathrm{MM} \mathrm{H}_{2} \mathrm{O}_{2}$ induces ROS levels similar to those observed in ischemia/reperfusion or respiratory burst conditions [24]. Alternatively, cells were exposed to $5 \mathrm{mM}$ hydrogen peroxide $\left(\mathrm{H}_{2} \mathrm{O}_{2}\right)$ or $20 \square \mathrm{M}$ etoposide for 30 min. $5 \mathrm{mM} \mathrm{H}_{2} \mathrm{O}_{2}$ induces ROS levels similar to those observed in vivo during acute inflammatory reactions. Etoposide is an inhibitor of the topoisomerase II religation reaction and a known inducer of DNA double-strand breaks (DSBs). 20IM etoposide is in close agreement with pharmacokinetic studies demonstrating peak patient plasma levels [25].

As expected, ROS and DSBs induced a dosedependent response of cell cycle arrest and cell death. Cell cycle profiles by BrdU analysis of cells exposed to all three conditions demonstrated G2 cell cycle arrest through 6 hrs post-exposure and release by 24 hrs post-exposure (data not shown). Cells exposed to etoposide demonstrated an intra-S phase arrest at early times and release by $24 \mathrm{hrs}$ post-exposure. The lack of a significant G1/S arrest was expected since ES cells have a defective p53mediated stress response [26-28]. $100 \mu \mathrm{M} \mathrm{H} \mathrm{H}_{2} \mathrm{O}_{2}$ induced minimal cell death; however, doses beyond $200 \mu \mathrm{M}$ induced significant cell death by $24 \mathrm{hrs}$ post-exposure $\left(\mathrm{IC}_{50}=5 \mathrm{mM}\right)$, relative to controls, Fig. (1A).

Pulse field gel electrophoresis along with $\mathrm{S} 1$ nuclease digestion confirmed ES cells had a dosedependent SsDNA digestion of chromatin DNA that led to $0.3-1 \mathrm{Mb}$ fragments, capable of inefficient religation and cell survival [29]. There was minimal ssDNA fragmentation following $100 \rrbracket \mathrm{M} \mathrm{H} \mathrm{H}_{2} \mathrm{O}_{2}$ and more significant fragmentation at higher toxic exposures, Fig. (1B). $50 \mathrm{~kb}$ DNA fragments were not detectable following acute 30 min exposure up to $10 \mathrm{mM}$ of $\mathrm{H}_{2} \mathrm{O}_{2}$. Only when ES cells were exposed to $100 \square \mathrm{M}$ of $\mathrm{H}_{2} \mathrm{O}_{2}$ continuously for 24 hrs were 50kb DNA fragments produced, but without oligonucleosomal fragmentation, Fig. (1C).

\section{Transcriptional response}

Immediate cellular transcriptional response following a transient minimally toxic exposure to ROS was determined using Affymetrix MGU74VerA chips and MS 5.0 and GeneSpring software comparing four samples exposed to the minimally toxic $\mathrm{H}_{2} \mathrm{O}_{2}$, five samples exposed to acute $\mathrm{H}_{2} \mathrm{O}_{2}$, and three replicate control samples. Among all conditions, 2742 transcripts were found significantly altered ( $p \leq 0.05)$, and, of these, 501 (433 known, 68 unknown) transcripts had a two-fold or greater change. Real-time RT-PCR results of 19 selected transcripts were concordant with microarray results. Correlation coefficient values for 16 of 19 transcripts were $r_{(100)}=0.71$ and $r_{(5)}=0.78$ for the two exposures to ROS, Table (1).

Transient exposure to a minimally toxic dose of $\mathrm{H}_{2} \mathrm{O}_{2}$ was sufficient to induce down-regulation of 185 transcripts and up-regulation of 175 transcripts. The response signature was distinct from a transient exposure to an acute dose that induced down-regulation of 114 transcripts and up-regulation of 62 transcripts. Overall, only 19 transcripts were commonly down-regulated and 12 transcripts commonly up-regulated by the two exposures (31 total; Table (2), Fig. (2B)) suggesting major differences, rather than common mechanisms, of immediate cellular response between minimally toxic and acute ROS exposure. A distinct cellular response to ROS exposures was further supported by an inverse dose effect in 11 transcripts, similar to studies in mammalian cells and yeast exposed to low or acute doses of irradiation [30,31] (Out of 360 transcripts altered following minimally toxic ROS and 176 following acute ROS, the expected false 
discovery rate would be $0.25 \%$, or 2 transcripts). Four transcripts (calm/4, cdkn1c, S100a6, gap43) were significantly decreased after minimally toxic ROS but increased after acute ROS, as compared to untreated samples. Conversely, seven transcripts (phtr1, dab2, bhmt2, prg1, sox17, gata6 and col4a1) were significantly increased after the minimally toxic ROS but decreased after acute ROS, as compared to untreated samples.

\section{Maintenance of stem cell markers}

Transient minimally toxic exposure to ROS revealed no significant change in 14 of 19 common transcripts associated with stem cell populations and pluripotency including signature transcripts oct3/4, nanog and sox2, Table (3) [32]. Markers specific for differentiation of ES cells upon LIF withdrawal were unchanged [33]. Three stem cell transcripts with known roles in DNA or stress response (Mdr1/abcb1 and ercc5 and gpx3) were up-regulated following a minimally toxic dose of $\mathrm{H}_{2} \mathrm{O}_{2}$, Table (3) $[12,34]$. Increases in SOD activity can reduce growth and malignant phenotypes of tumor cells in culture although its mechanism of action is not well understood and can be inconsistent $[23,35,36]$. However, in this study, ROS led to down-regulation of sod2, a stem cell marker identified by Sartzki et. al [12], suggesting the promotion of growth and survival of mouse ES cells following a single minimally toxic exposure. Two transcripts (gbx2 [37], c-myc [38]) were downregulated. Gbx2 is within the wnt pathway and not a known myc target gene ([39]; http://www.myccancergene.org/index.asp). Overall, these results suggest that pluripotent stem cell populations have the capacity to respond to ROS while retaining their major self-renewal signatures.

\section{Oncogenic immediate transcriptional signature response}

Transcriptional profiles were assessed by GO, Entrez, Locuslink, and Ingenuity Pathway Analysis (IPA) (Ingenuity® Systems, www.ingenuity.com). Pathway analysis demonstrated the minimally toxic and acute ROS stratified top significantly altered biological functions, Table (4). IPA functionally classified all altered transcripts according to tumorigenesis, DNA repair, cell growth/maintenance, development, cell cycle, and pro- or anti-apoptosis (Table 3). IPA noted a significant number of altered transcripts classified in tumorigenesis $(139 / 360 ; 39 \%)$ following the single minimally toxic dose of $\mathrm{H}_{2} \mathrm{O}_{2}$, specifically a significant up-regulation of oncogenes and downregulation of tumor suppressors, Table (4), Fig. (3). Consistent with this, IPA noted a significant upregulation of anti-apoptotic transcripts, Fig. (3). The additional IPA classifications did not reveal significant clustering. These data indicate a nonlinear relationship and strong association between
ROS dose and oncogene activation or tumor suppressor silencing, along with cell survival.

\section{Oncogenic immediate post-translational signature response}

To more completely assess the signaling pathways induced in stem cells by a transient and minimally toxic exposure to ROS, we used Kinexus $\circledast$ phospho-proteomic screening technology to analyze 92 phosphorylation sites covering 53 proteins in $\mathrm{p} 53, \mathrm{Rb}, \mathrm{p38/MAPK/ERK}, \mathrm{NFkB}$, PI3K/Akt and insulin-signaling pathways, Table (5). Reproducibility was validated by detecting concordant normalized CPM values for common epitopes (Mapk1-T185+Y187, Mapk3-T202+Y204, p38Mapk-T180+Y182). Samples were exposed to $100 \mathrm{M} \mathrm{H}_{2} \mathrm{O}_{2}$ for $15 \mathrm{~min}$, recovered in normal media for $1 \mathrm{hr}$, then harvested for analysis. Specificity of the response was determined by comparison against a 15 min exposure to $5 \mathrm{mM} \mathrm{H}_{2} \mathrm{O}_{2}$ or $30 \mathrm{~min}$ exposure to 20:M etoposide. Based on an absolute cut-off of 300 normalized CPM, nearly two-thirds (52 of 92) of the epitopes had no detectable phosphorylation in either control samples or following ROS or etoposide exposure. The remaining third of epitopes (34 of 92) had a detectable baseline phosphorylation in control samples. We focused on sites that were found differentially phosphorylated by at least $25 \%$ with respect to controls. $85 \%$ (29 of 34 ) of these were altered one hour following exposure to either ROS or etoposide, Table (5).

Overall, stem cell response to ROS was distinct from etoposide exposure and could be stratified by dose, with a specific phosphorylation pattern induced by each. Only 5 of the 34 epitopes (15\%) with baseline phosphorylation were posttranslationally altered by both $\mathrm{H}_{2} \mathrm{O}_{2}$ and etoposide treatment--activating phoshorylation of $\mathrm{CDC} 2$ (CDK1) at T160/161 and of p38a MAPK at $\mathrm{T} 180+\mathrm{Y} 182$, activating dephosphorylation of the catalytic subunit $\square$ of protein phosphatase 1 (PPP1CA) at T320 and of MAP2K1 (MEK1) at T291, and inhibitory phosphorylation of elF2B5 at S539. Decreased phosphorylation of elF2B5 would be expected as a consequence of slowed translation in response to DNA damage and stress. These results suggest that the immediate response to DNA damage involves changes to homeostatically phosphorylated proteins in ES cells rather than phosphorylation of new ones, at least within the signaling pathways examined.

Eight epitopes were hypophosphorylated and 7 epitopes were hyperphosphorylated in response to 100IM $\mathrm{H}_{2} \mathrm{O}_{2}$. Consistent with the IPA analysis of transcriptional response, exposure to $100 \mathrm{M} \mathrm{M} \mathrm{H}_{2} \mathrm{O}_{2}$ uniquely induced hypophosphorylation of protein kinase $\mathrm{C}$ related kinase (Prk1) at $T 778$ associated with cell migration and tumor metastasis and 
hyperphosphorylation of Npm1 at S4 associated with cell survival and growth, Table (5).

Transient exposure to minimally toxic $100 \square \mathrm{M} \mathrm{H}_{2} \mathrm{O}_{2}$ uniquely led to dysregulated insulin signaling activation observed by hypophosphorylation of insulin receptor (INSR) at Y972, Table (5). This response was supported by increased phosphorylation of GSK3 $\llbracket$ at S21 and increased phosphorylation of FAK/Ptk2 at S910, Table (5). The INSR juxtamembrane autophosphorylation site Y972 promotes interaction and stability between INSR and intracellular substrates [40] while FAK1 acts as an intracellular positive downstream regulator of signaling. Hypophosphorylation of INSR at Y972, phosphorylation of FAK1, and inhibitory phosphorylation of GSK3 at S21 have all been associated with insulin-resistant signaling. Further, protein kinase B/Akt1 plays a role in multiple signaling pathways including insulin-stimulated GLUT4 membrane localization[41]. Partial activation of Akt by $\$ 473$ phosphorylation, essential for Akt activation, was observed in a dose-dependent manner.

\section{Discussion}

Defining the cellular response of stem cells to ROS is critical to understanding the unique sensitivity of stem cells to minimally toxic episodes of ROS exposure, or a minimal threshold dose of ROS, to initiate disease or cellular transformation. In this study we directly examined the response of ES cells to a single transient and minimally toxic exposure of ROS and correlated the immediate transcriptional and post-translational modifications that resulted.

ES cells demonstrated a high resistance to ROS consistent with previous work showing ES cells withstanding extreme hyperoxic conditions (40\% $\mathrm{O}_{2}$ ) compared with cells grown under normoxic culture conditions [12]. ES cells were more resistant to OS-induced high molecular weight DNA fragmentation than differentiated cell types $[29,42]$. ES cells may have an increased DNA repair capacity or endonuclease-protected higher order chromatin similar to some cancer cell lines $[43,44]$. Consistent with this, the dose-dependent resistance of ES cells to ROS-mediated cell death was similar to Caco2 colon cancer cells and elevated compared to terminally differentiated primary glial cells $[44,45]$. Low and high dose ROS-inducing therapies have different cytotoxicities and short- and long-term efficacies $[46,47]$ that are likely defined by the immediate cell-specific response to these treatments, similar to the observations made here. Consistent with increased resistance of ES cells to ROS, transcripts of the majority of canonical selfrenewing genes were similarly unaffected by $100 \mathrm{IM}$ $\mathrm{H}_{2} \mathrm{O}_{2}$. Following this minimally toxic episode of ROS, we did not observe a significant change in transcripts known to be affected following LIF withdrawal-induced differentiation of ES cells [33].
However, a mild transcriptional signal of differentiation could be discerned following acute levels.

Binning of significant biological functions determined that a minimally toxic ROS exposure primarily affected transcription of tumorigenesisrelated genes. We curated oncogenes and tumor suppressors and found a significant proportion of oncogenes were up-regulated and tumor suppressors were down-regulated uniquely following $100 \square \mathrm{M} \mathrm{H}_{2} \mathrm{O}_{2}$. This is direct evidence of an oncogenic transcriptional signature induced specifically following a transient and minimally toxic ROS exposure. We did not observe any significant up-regulation in transcripts of classical antioxidant or DNA repair genes following either minimally toxic or acute dose, similar to studies in yeast models [14].

Results showed that early post-translational response to ROS affects mainly homeostatically phosphorylated proteins rather than phosphorylation of new moieties. Focusing on regulated resting state phosphorylated sites, we discerned no apparent paradigm of stem cell response to multiple genotoxic exposures indicating that unique responses might be specific to each compound. Consistent with the transcriptional data, transient exposure to a minimally toxic dose of of $\mathrm{H}_{2} \mathrm{O}_{2}$ specifically increased oncogenic (e.g. hypophosphosphorylation of RAF1 at S259, hyperphosphosphorylation of NPM1 at S4) and metastatic (hypophosphosphorylation of PTK2 at S910) signals common to pathways leading to survival, growth and proliferation, G2/M transition and migration.

We previously demonstrated that etoposide induces similar cytotoxic and genotoxic effects as the minimally toxic ROS used here [48]; however, posttranslational response to the two agents was distinct. Early signaling induced by etoposide could be distinguished from that of ROS through activation of [-catenin survival pathway and reduction of integrin and migration signaling as well as an inhibition of the $47 \mathrm{kD}$ isoform of JNK. These data provide evidence that a single exposure to mild ROS is sufficient to promote a distinct cellular response marked by significant oncogenic signals that may intitiate cell transformation in a surviving stem cell population.

We were surprised to observe activating marks of survival (e.g. hyperphosphorylated Akt at S473), growth (e.g. hypophosphorylated 70kD RAF1 isoform at S910), and proliferation (e.g. hyperphosphorylated Prkcm at $\mathrm{S} 916$ and hypophosphorylation of Ptk2 at S722) in ES cells one hour following a transient exposure to ROS suggesting that ES cells' initial response to stress is to maintain a rapid growth rate and bypass DNA repair. This initial rapid growth is then temporally followed by the well characterized induction of cell 
cycle checkpoints and reduced E2F-dependent transcription, manifested by almost complete dephosphorylation of $\mathrm{Rb}$ at $\mathrm{S} 773$, hyperphosphorylation of cdc2 at $\mathrm{Y} 15$, and supported by transcriptional microarray data showing down-regulation of $\mathrm{E} 2 \mathrm{~F}$ targets such as foxd3.

This study demonstrated that a single minimally toxic exposure to ROS uniquely led to dysregulated insulin signaling. The tyrosine kinase insulin receptor (INSR) is required to mediate insulin signaling, and the early steps of INSR activation are well understood. INSR is a heterotetrameric membrane glycoprotein composed of two $\square$ and two q subunits, linked together by disulfide bonds with activation cascade initiated by binding of insulin to the receptor's extracellular [-subunit $[49,50]$. The INSR tyrosine kinase is activated upon binding of insulin binds to the receptor's extracellular l-subunit, initiating subunit colocalization, conformational changes, autophoshorylation, and activation of the receptor's kinase activity on intracellular protein substrates [49,50]. Mutations in the INSR gene can reduce receptor autophosphorylation and tyrosine kinase activity toward an exogenous substrate, resulting in both in vivo and in vitro insulin resistance and diabetes mellitus [51-56]. In our study, a transient minimally toxic exposure to ROS mediated by $\mathrm{H}_{2} \mathrm{O}_{2}$ was sufficient to induce immediate hypophosphorylation of Y972 providing a direct link between ROS and insulin resistance. Y972F mutation has been shown to cause severe impairment of downstream effector IRS-1 adaptor tyrosine phosphorylation and, thus, downstream signaling of the insulin pathway [57]. Further, Y972 hypophosphorylation in HEK cells was shown to be dependent on Grb14 which is over-expressed in insulin resistance mouse models and human Type II diabetic patients [58]. In support of the suggestion that appropriate insulin signaling is altered by ROS, we also observed an almost 2-fold increase in the inhibitory S21 phosphorylation of GSK3. GSK3 is active in a cell's resting state and inhibited by insulin, and complete inhibition of GSK3 by acute insulin exposure occurs through phosphorylation of Ser21. It has been shown that over-expression of GSK3 impairs insulin responsiveness while knockdown of GSK3 improves insulin action [59]. GSK3 is elevated in patients with poorly controlled type 2 diabetes and animal models of insulin resistance $[60,61]$. Taken together, our data shed new light on the possible mechanism of even transient mild ROS exposure on hypophosphorylation of INSR and insulin resistance $[58,62,63]$.

Overall, this screen demonstrated that ES cell early response to ROS is dose dependent and a single transient minimally toxic exposure is sufficient to promote an early post-translational response with significant oncogenic signals supporting the transcriptional data. In addition to new data related to stem cell signaling, this work supports the hypothesis that cancer emanates from a transformed stem cell and underscores the potential role of even a single exposure to ROS to promote this transformation. These data underscore the importance of deciphering methods to either spare wild type stem cells from transformation after ischemia/reperfusion or chemotherapy approaches or to target cancer stem cells.

\section{Materials and Methods}

DNA damage and oxidative stress. E14TG2aderived mouse embryonic stem (ES) cells were cultured as previously described [64,65]. $2 \times 10^{7}$ cells in suspension were exposed to one of the following: $2 \mathrm{ml}$ PBS containing $100 \mu \mathrm{M}$ or $5 \mathrm{mM}$ hydrogen peroxide for 15 and $30 \mathrm{~min}, 20 \mu \mathrm{M}$ etoposide (Sigma-Aldrich; $20 \mathrm{mM}$ stock solution prepared in dimethylosulphoxide (DMSO)) for 30 min, or PBS alone. Cells were replated and recovered for $1 \mathrm{hr}$ at $37^{\circ} \mathrm{C}$ in $5 \% \quad \mathrm{CO}_{2}$ before harvest.

Cell cycle analysis and growth arrest. $5 \times 10^{6}$ cells were plated in $10 \mathrm{~cm}$ dishes and allowed to recover for $24 \mathrm{hr}$. Adherent cells were harvested and viable cells determined by hemocytometer and trypan blue exclusion or by BrdU labeling.

Pulse Field Gel Electrophoresis. Treated cells were suspended in embedding buffer $(15 \mathrm{mM}$ Tris$\mathrm{HCl}, \mathrm{pH} 7.4,1 \mathrm{mM}$ EGTA, $60 \mathrm{mM} \mathrm{KCl}, 15 \mathrm{mM} \mathrm{NaCl}$, 2mM EDTA, 0.5mM spermidine, $0.15 \mathrm{mM}$ spermine), embedded in $0.8 \%$ low melting agarose at $40^{\circ} \mathrm{C}$, casted in BioRad plugs (ca\# 170-3622) $\left(3 \times 10^{5}\right.$ cells per $50 \mathrm{\mu l}$ ) then cooled for $1 \mathrm{~min}$ at $-20^{\circ} \mathrm{C}$. Lipid and protein extraction was performed by two overnight incubations in extraction buffer $110 \mathrm{mM}$ Tris- $\mathrm{HCl}, \mathrm{pH} 9.5,10 \mathrm{mM} \mathrm{NaCl}, 25 \mathrm{mM}$ EDTA, $1 \mathrm{mM}$ EGTA, $1.5 \%$ SDS, $0.1 \%$ mercaptoethanol) at room temperature and gentle rocking. Plugs were washed three times in $\mathrm{TE} \mathrm{pH} 7.6$ for two hours each followed by RNA digestion with RNase for one $\mathrm{hr}$ at $37^{\circ} \mathrm{C}$. Proteinase $\mathrm{K}$ digestion for 6 hours at $50^{\circ} \mathrm{C}$ was followed by washing in $\mathrm{TE}$ pH 7.6 three times for two hours each. For single strand break analysis, DNA plugs were digested with 3 units S1 nuclease for one hour at $37^{\circ} \mathrm{C}$ in $200 \mu \mathrm{S} 1$ nuclease buffer (30mM NaAc pH 4.6, $100 \mathrm{mM} \mathrm{NaCl}$, $0.5 \mathrm{mM} \mathrm{ZnCl}$ ). DNA breaks were analyzed by field inversion gel electrophoresis (FIGE). Plugs containing purified DNA were inserted in wells of $1 \% 0.5 X$ TBE pulse field-certified agarose gel and resolved by BioRad CHEF Mapper (ca\# 170-3670) at $14^{\circ} \mathrm{C} 0.5 \mathrm{X}$ TBE buffer circulated by a pump, 20 min of forward voltage $(6 \mathrm{v} / \mathrm{cm})$ without field reversion. Resolution of DNA was programmed as: forward voltage: $5 \mathrm{~V} / \mathrm{cm}$, forward initial switch time: $0.3 \mathrm{~s}$, forward final switch time: 30 s, reverse voltage: 
$5 \mathrm{~V} / \mathrm{cm}$, reverse initial switch time: $0.1 \mathrm{~s}$, reverse final switch time: 10 s, $A=$ linear, Run time: 16 hours. Following electrophoresis, gel was stained with ethidium bromide and DNA visualized by UV.

Microarray hybridization and analysis. Samples were exposed to $\mathrm{H}_{2} \mathrm{O}_{2}$ for 15 min, recovered for 1 $\mathrm{hr}$, then harvested for analysis. cRNA derived from $10 \mu \mathrm{g}$ of total RNA from treated cell samples was prepared and hybridized to MG_U74Av2 oligonucleotide chip according to Affymetrix's protocol. Prior to filtering, unsupervised hierarchical clustering using standard correlation as a similarity measure algorithm confirmed the relatedness of samples within treatment groups (Supplemental Fig. S1A). "Absent" calls in at least 10 out of 12 samples were filtered, leaving 6970 transcripts (out of $12,488)$ and consistent with previous data that ES cells express approximately $30 \%$ of potential transcripts [66]. Analysis of variance in gene expression between control group of replicates and one of the treated groups was performed using the Welch t-test with a 2 fold or greater change and a $p$ value of 0.05 or lower. Per gene and chip normalization was used as well as the Cross Gene Error Model. Gene expression normalized values were analyzed using GeneSpring GX software (Agilent Technologies). Data is available at http://www.ncbi.nlm.nih.gov/geo/ Accession number \#GSE18708 and http://biology.uncc.edu/Faculty/ Richardson/index.htm. SYBR ${ }^{\circledR}$ green and LightCycler $^{\circledR}$ real-time RT-PCR was used to validate data.

Phosphoprotein Analysis. Samples were exposed to $\mathrm{H}_{2} \mathrm{O}_{2}$ for $15 \mathrm{~min}$, recovered for $1 \mathrm{hr}$, then harvested for analysis. Cells were washed in ice cold PBS, lysed in $500 \mu \mathrm{l}$ lysis buffer $(150 \mathrm{mM}$ $\mathrm{NaCl}, 20 \mathrm{mM}$ Tris pH 8.0, 0.5\% (w/v) Nonidet P-40, $1 \mathrm{mM}$ dithiothreitol (DTT), $20 \mathrm{mM} \quad \beta$ glycerophosphate, $\quad 1 \mathrm{mM} \quad \mathrm{Na}_{3} \mathrm{VO}_{4}, \quad 1 \mathrm{mM}$ phenylmethylsulfonyl fluoride, $10 \mu \mathrm{g} / \mathrm{ml}$ aprotinin, $10 \mu \mathrm{g} / \mathrm{ml}$ leupeptin and $1 \mu \mathrm{g} / \mathrm{ml}$ pepstatin A) and sonicated for $30 \mathrm{sec}$ pulsing $1 \mathrm{sec}$ ON $1 \mathrm{sec}$ OFF. Cell debris was removed by centrifugation at $13,000 \mathrm{rpm}$ for $15 \mathrm{~min}$ at $4^{\circ} \mathrm{C}$. Protein concentration was determined by the Bradford assay. Samples were performed in triplicates. For phosphoscreening the Kinetworks ${ }^{\mathrm{TM}}$ platform was used (Kinexus-KPSS-2 and KPSS-4). Images available at http://biology.uncc.edu/Faculty/Richardson/index.ht m. $300 \mu \mathrm{g}$ of total protein were resolved on a $13 \%$ single lane SDS-polyacrylamide gel and transferred to nitrocellulose membrane. The membrane was incubated with mixtures of up to three antibodies per lane that react with a distinct subset of at least 95 known phosphorylated sites on 53 cell signaling proteins of distinct molecular masses, then horseradish peroxidase-conjugated secondary antibodies (Santa Cruz Biotechnology). Blots were developed using ECL Plus reagent (Amersham
Biosciences) and signals were quantified using Quantity One software (Bio-Rad). The overall early response to OS or etoposide is similar with a Spearman correlation value of 0.94 between etoposide and low OS dose, 0.89 between etoposide and high dose, and 0.90 between low dose and high dose. However, the correlation of response with respect to treatment drops significantly to $0.3-0.4$ when only the affected epitopes are analyzed indicating that each treatment can be correlated with a unique identifier.

\section{Acknowledgements}

We gratefully acknowledge the assistance of Vladin M. of the Columbia University Microarray Core Facility in microarray sample preparation. $\mathrm{CR}$ is supported by NCI/NIH (2R01-CA100159).

\section{References}

[1] Jackson, A.L. and Loeb, L.A. (2001) Mutation Res, 477, 7-21.

[2] Davies, K.J. (1995) Biochem Soc Symp 61, 1-31.

[3] Beckman, K.B. and Ames, B.N. (1997) J Biol Chem, 272, 19633-6.

[4] Waris, G. and Ahsan, H. (2006) J Carcinog, 5, 14.

[5] Burdon, R.H. (1995) Free Radic Biol Med, 18, 775-94.

[6] Burdon, R.H., Alliangana, D. and Gill, V. (1995) Free Radic Res, 23, 471-86.

[7] Olinski, R., Gackowski, D., Foksinski, M., Rozalski, R., Roszkowski, K. and Jaruga, P. (2002) Free Radic Biol Med, 33, 192200.

[8] Wang, M.C., Bohmann, D. and Jasper, $\mathrm{H}$. (2003) Dev Cell, 5, 811-6.

[9] Baysal, B.E. (2003) Trends Endocrinol Metab, 14, 453-9.

[10] Baysal, B.E. (2007) PLoS ONE, 2, e436.

[11] Hayes, G.R. and Lockwood, D.H. (1987) Proc Natl Acad Sci U S A, 84, 8115-9.

[12] Saretzki, G., Armstrong, L., Leake, A., Lako, M. and von Zglinicki, T. (2004) Stem Cells, 22, 962-71.

[13] Francis, R. and Richardson, C. (2007) Genes Dev, 21, 1064-74.

[14] Birrell, G.W., Brown, J.A., Wu, H.I., Giaever, G., Chu, A.M., Davis, R.W. and Brown, J.M. (2002) Proc Natl Acad Sci U $S A, 99,8778-83$.

[15] Weigel, A.L., Handa, J.T. and Hjelmeland, L.M. (2002) Free Radic Biol Med, 33, 1419-32.

[16] Anantharam, V., Lehrmann, E., Kanthasamy, A., Yang, Y., Banerjee, P., Becker, K.G., Freed, W.J. and Kanthasamy, A.G. (2007) Neurochem Int, $50,834-47$ 
[17] Purdom-Dickinson, S.E., Lin, Y., Dedek M., Morrissy, S., Johnson, J. and Chen, Q.M. (2007) J Mol Cell Cardiol, 42, 15976.

[18] Chuang, Y.Y. et al. (2002) Cancer Res, 62, 6246-54

[19] Yu, Q., He, M., Lee, N.H. and Liu, E.T. (2002) J Biol Chem, 277, 13059-66.

[20] Amundson, S.A., Do, K.T., Vinikoor, L. Koch-Paiz, C.A., Bittner, M.L., Trent, J.M., Meltzer, P. and Fornace, A.J., Jr. (2005) Oncogene, 24, 4572-9.

[21] Zhang, Y., Fong, C.C., Wong, M.S., Tzang, C.H., Lai, W.P., Fong, W.F., Sui, S.F. and Yang, M. (2005) Apoptosis, 10, 545-56.

[22] Islaih, M. et al. (2005) Mutation Res, 578, 100-16.

[23] Allen, R.G. and Tresini, M. (2000) Free Radic Biol Med, 28, 463-99.

[24] Halliwell, B., Clement, M.V. and Long, L.H. (2000) FEBS Letters, 486, 10-3.

[25] Hardman, J., Limbird, L. and Goodman Gilman, A. (2001) A pharmacological basis of therapeutics, Mc-Graw Hill. New York.

[26] Aladjem, M.I., Spike, B.T., Rodewald, L.W., Hope, T.J., Klemm, M., Jaenisch, R. and Wahl, G.M. (1998) Curr Biol, 8, 14555.

[27] Corbet, S.W., Clarke, A.R., Gledhill, S. and Wyllie, A.H. (1999) Oncogene, 18, 1537-44.

[28] Sabapathy, K., Klemm, M., Jaenisch, R. and Wagner, E.F. (1997) EMBO J, 16, 6217-29.

[29] Mouzannar, R., Miric, S.J., Wiggins, R.C. and Konat, G.W. (2001) Neurochem Int, 38, 9-15.

[30] Furuno-Fukushi, I., Tatsumi, K., Takahagi, M. and Tachibana, A. (1996) Int J Radiat Biol, 70, 209-17.

[31] Vilenchik, M.M. and Knudson, A.G. (2003) Proc Natl Acad Sci U S A, 100, 12871-6.

[32] Eckfeldt, C.E., Mendenhall, E.M. and Verfaillie, C.M. (2005) Nat Rev Mol Cell Biol, 6, 726-37.

[33] Duval, D. et al. (2006) Cell Death Differ, 13, 564-75

[34] Ramalho-Santos, M., Yoon, S., Matsuzaki, Y., Mulligan, R.C. and Melton, D.A. (2002) Science, 298, 597-600.

[35] Yan, T., Oberley, L.W., Zhong, W. and St Clair, D.K. (1996) Cancer Res, 56, 286471.

[36] Zhong, W., Oberley, L.W., Oberley, T.D. and St Clair, D.K. (1997) Oncogene, 14, 481-90.

[37] Rathjen, J., Lake, J.A., Bettess, M.D., Washington, J.M., Chapman, G. and
Rathjen, P.D. (1999) J Cell Sci, 112 ( Pt 5), 601-12.

[38] Cartwright, P., McLean, C., Sheppard, A., Rivett, D., Jones, K. and Dalton, S. (2005) Development, 132, 885-96.

[39] Katoh, Y. and Katoh, M. (2005) Int J Oncol, 27, 581-5.

[40] Kido, Y., Nakae, J. and Accili, D. (2001) J Clin Endocrinol Metab, 86, 972-9.

[41] Coffer, P.J., Jin, J. and Woodgett, J.R. (1998) Biochem, J 335 ( Pt 1), 1-13.

[42] Kaneko, S. et al. (2006) J Pharmacol Sci, 101, 66-76.

[43] Bai, H. and Konat, G.W. (2003) Neurochem Int, 42, 123-9.

[44] Wijeratne, S.S., Cuppett, S.L. and Schlegel, V. (2005) J Agric Food Chem, $53,8768-74$.

[45] Konat, G.W., Mouzannar, R. and Bai, H. (2001) Neurochem Int, 39, 179-86.

[46] Han, W., Takano, T., He, J., Ding, J., Gao, S., Noda, C., Yanagi, S. and Yamamura, H. (2001) Antioxid Redox Signal, 3, 1065-73.

[47] Raffaghello, L., Lee, C., Safdie, F.M., Wei, M., Madia, F., Bianchi, G. and Longo, V.D. (2008) Proc Natl Acad Sci U S A, 105, 8215-20.

[48] Libura, J., Slater, D.J., Felix, C.A. and Richardson, C. (2005) Blood, 105, 212431.

[49] Hubbard, S.R. (1997) EMBO J, 16, 557281.

[50] Hubbard, S.R., Wei, L., Ellis, L. and Hendrickson, W.A. (1994) Nature, 372, 746-54.

[51] Moller, D.E. and Flier, J.S. (1988) N Engl J Med, 319, 1526-9.

[52] Odawara, M. et al. (1989) Science, 245, 66-8.

[53] Taira, M. et al. (1989) Science, 245, 63-6.

[54] Grunberger, G., Zick, Y. and Gorden, P. (1984) Science, 223, 932-4.

[55] Le Marchand-Brustel, Y., Gremeaux, T., Ballotti, R. and Van Obberghen, E. (1985) Nature, 315, 676-9.

[56] Freidenberg, G.R., Henry, R.R., Klein, H.H., Reichart, D.R. and Olefsky, J.M. (1987) J Clin Invest, 79, 240-50.

[57] Kaburagi, Y. et al. (1993) J Biol Chem, 268, 16610-22.

[58] Nouaille, S., Blanquart, C., Zilberfarb, V., Boute, N., Perdereau, D., Burnol, A.F. and Issad, T. (2006) Biochem Pharmacol, 72, 1355-66.

[59] Ciaraldi, T.P., Nikoulina, S.E., Bandukwala, R.A., Carter, L. and Henry, R.R. (2007) Endocrinology, 148, 4393-9. 
[60] Eldar-Finkelman, H., Schreyer, S.A., Shinohara, M.M., LeBoeuf, R.C. and Krebs, E.G. (1999) Diabetes, 48, 1662-6.

[61] Nikoulina, S.E., Ciaraldi, T.P., Mudaliar, S., Mohideen, P., Carter, L. and Henry, R.R. (2000) Diabetes, 49, 263-71.

[62] Dokken, B.B., Saengsirisuwan, V., Kim, J.S., Teachey, M.K. and Henriksen, E.J. (2008) Endocrinol Metab, 294, E615-21.

[63] Goldstein, B.J., Mahadev, K., Wu, X., Zhu, L. and Motoshima, H. (2005) Antioxid Redox Signal, 7, 1021-31.

[64] Hooper, M., Hardy, K., Handyside, A. Hunter, S. and Monk, M. (1987) Nature, 326, 292-5.

[65] Richardson, C. and Jasin, M. (2000) Nature, 405, 697-700.

[66] Eckfeldt, C.E., Mendenhall, E.M., Flynn, C.M., Wang, T.F., Pickart, M.A., Grindle, S.M., Ekker, S.C. and Verfaillie, C.M. (2005) PLoS Biol, 3, e254. 
Table 1- Real-time qPCR validation of transcriptional microarray results

\begin{tabular}{|c|c|c|c|c|c|}
\hline & \multicolumn{2}{|c|}{ Microarray } & \multicolumn{2}{|c|}{ Real Time qPCR } & \\
\hline & $100 \mu \mathrm{M}-15 \mathrm{~min}$ & $5 \mathrm{mM}-30 \mathrm{~min}$ & $100 \mu \mathrm{M}-15 \mathrm{~min}$ & $5 \mathrm{mM}-30 \mathrm{~min}$ & \\
\hline Mito (EST) & $2.1 \pm 0.3$ & $2.5 \pm 0.3$ & $1.7 \pm 0.3$ & $1.9 \pm 0.2$ & \multirow{9}{*}{ 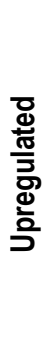 } \\
\hline Ysg2 & $2 \pm 0.2$ & $2.1 \pm 0.5$ & $1.8 \pm 0.4$ & $2.3 \pm 0.5$ & \\
\hline Zfp143 & $3.7 \pm 0.5$ & $3.5 \pm 0.8$ & $2.7 \pm 0.7$ & $2.7 \pm 1.1$ & \\
\hline Sgpp1 & $2 \pm 0.8$ & $2 \pm 0.7$ & $2.2 \pm 0.6$ & $1.5 \pm 0.4$ & \\
\hline Phldb2 & $12.6 \pm 3$ & $2.2 \pm 1.3$ & $4.8 \pm 1.4$ & $1.4 \pm 0.5$ & \\
\hline Slc23a3 & $2.7 \pm 0.7$ & $2.1 \pm 1$ & $13.5 \pm 4.5$ & $2.4 \pm 1.1$ & \\
\hline Ub-Lig (EST) & $3 \pm 0.6$ & $4.7 \pm 1.4$ & $4.7 \pm 1.4$ & $6.3 \pm 0.8$ & \\
\hline Id2 & $1.9 \pm 0.3$ & $1 \pm 0.2$ & $3.5 \pm 0.9$ & $1.7 \pm 0.6$ & \\
\hline Id4 & $2.7 \pm 0.3$ & $0.7 \pm 0.2$ & $4 \pm 1.2$ & $1.1 \pm 0.1$ & \\
\hline nab1 & $2 \pm 0.6$ & $3 \pm 0.3$ & $2.1 \pm 0.5$ & $2.8 \pm 0.9$ & \multirow{10}{*}{ 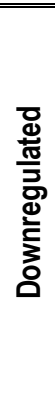 } \\
\hline nab2 & $2.4 \pm 0.7$ & $2.7 \pm 0.6$ & $2.3 \pm 0.4$ & $3.7 \pm 0.8$ & \\
\hline Gbx2 & $10.5 \pm 1.6$ & $3.4 \pm 0.7$ & $6.2 \pm 0.7$ & $3.2 \pm 0.5$ & \\
\hline Bmp4 & $5.3 \pm 0.6$ & $2.8 \pm 0.4$ & $4.9 \pm 0.7$ & $2.1 \pm 0.2$ & \\
\hline c-myc & $5.44 \pm 0.9$ & $2.2 \pm 0.5$ & $2.7 \pm 0.5$ & $1.9 \pm 0.2$ & \\
\hline Atp11a & $2.2 \pm 0.2$ & $2 \pm 0.4$ & $2.6 \pm 1$ & $1.9 \pm 0.6$ & \\
\hline Gt12 & $4.6 \pm 4$ & $3 \pm 5$ & $2.5 \pm 0.5$ & $1.2 \pm 0.3$ & \\
\hline Trp53 & $1.8 \pm 0.5$ & $1 \pm 0.1$ & $1 \pm 0.3$ & $1 \pm 0.2$ & \\
\hline fgfbp1 & $3.6 \pm 1.5$ & $13.4 \pm 8$ & $1.8 \pm 0.4$ & $4.1 \pm 0.8$ & \\
\hline \multirow[t]{2}{*}{ Id1 } & $2.5 \pm 0.3$ & $1 \pm 0.4$ & $1.9 \pm 0.7$ & $1.5 \pm 0.6$ & \\
\hline & $\overline{n=4}$ & $n=5$ & $n=8$ & $\mathrm{n}=10$ & \\
\hline
\end{tabular}

Correlation without 3 outliers highlighted in bold: $r(100)=0.71 ; r(5)=0.78$. Correlation with outliers: $r(100)=0.28$; $r(5)=0.57$ 
Table 2-Commonly regulated transcripts following minimally toxic and acute exposures to $\mathrm{H}_{2} \mathrm{O}_{2}$

\begin{tabular}{|c|c|c|c|c|}
\hline \multirow[b]{2}{*}{ Gene Name } & \multirow[b]{2}{*}{ Symbol } & \multirow[b]{2}{*}{ GenBank } & \multicolumn{2}{|c|}{$\begin{array}{c}\text { Fold change relative to no } \\
\text { treatment }\end{array}$} \\
\hline & & & $\begin{array}{c}100 \mu \mathrm{M} \\
15 \mathrm{~min} \\
\end{array}$ & $\begin{array}{c}5 \mathrm{mM} \\
30 \mathrm{~min}\end{array}$ \\
\hline \multicolumn{5}{|l|}{ upregulated } \\
\hline fibroblast growth factor binding protein 1 & Fgfbp1 & AF065441 & 3.6 & 13.4 \\
\hline sarco(endo)plasmic reticulum calcium ATPase & $\begin{array}{l}\text { Atp2a2; } \\
\text { SERCA2 }\end{array}$ & AF029982 & 2 & 6.3 \\
\hline Taglin; SM22 & Tagln; Sm22a & Z68618 & 2.8 & 3.5 \\
\hline gastrulation brain homeobox 2 & Gbx2 & Z48800 & 10.5 & 3.4 \\
\hline Ngfi-A binding protein 1 & Nab1 & U47008 & 2 & 3 \\
\hline $\begin{array}{l}\text { GTL2, imprinted maternally expressed } \\
\text { untranslated mRNA }\end{array}$ & Gt12 & Y13832 & 4.6 & 3 \\
\hline BMP-4 gene & Bmp4 & L47480 & 5.3 & 2.8 \\
\hline Ngfi-A binding protein 2 & Nab2 & U47543 & 2.4 & 2.7 \\
\hline EST00652 & & AA407332 & 2.3 & 2.7 \\
\hline $\begin{array}{l}\text { solute carrier family } 25 \text { (adenine nucleotide } \\
\text { translocator), member } 5\end{array}$ & Slc25a5 & U10404 & 2.8 & 2.6 \\
\hline Dusp6 & Dusp6 & Al845584 & 2.8 & 2.4 \\
\hline cytochrome c oxidase, subunit VIIc & Cox7c & Al648091 & 3.2 & 2.4 \\
\hline myeloid-associated differentiation marker & Myadm & AJ001616 & 2.1 & 2.3 \\
\hline c-myc exon 3 & c-myc & L00039 & 5.44 & 2.2 \\
\hline stratifin & Sfn & AF058798 & 2.9 & 2.1 \\
\hline urokinase plasminogen activator receptor & Plaur & $\mathrm{X} 62700$ & 2.6 & 2.1 \\
\hline CCR4 carbon catabolite repression 4-like & Ccrn4l & AW047630 & 3.3 & 2.1 \\
\hline Nes & Nes & AW061260 & 3 & 2 \\
\hline ATPase, class VI, type $11 \mathrm{~A}$ & Atp11a & AA690863 & 2.2 & 2 \\
\hline \multicolumn{5}{|l|}{ downregulated } \\
\hline $\begin{array}{l}\text { pleckstrin homology-like domain, family B, } \\
\text { member } 2\end{array}$ & Phldb2 & AW125043 & 12.6 & 2.2 \\
\hline receptor (calcitonin) modifying protein 2 & Ramp2 & AJ250490 & 6 & 2.7 \\
\hline zinc finger protein 143 & Zfp143 & U29513 & 3.7 & 3.5 \\
\hline protein kinase, lysine deficient 1 & Prkwnk1 & AV319920 & 3.2 & 2.2 \\
\hline RIKEN cDNA 2310014L17, ubiquitin ligase & 2310014L17Rik & AA794189 & 3 & 4.7 \\
\hline $\begin{array}{l}\text { solute carrier family } 23 \text { (nucleobase transporters), } \\
\text { member } 3\end{array}$ & Slc23a3 & AV222871 & 2.7 & 2.1 \\
\hline $\begin{array}{l}\text { (clone lambda-MG5.3) acid phosphatase type } 5 \\
\text { gene }\end{array}$ & Acp5; TRAP & M99054 & 2.4 & 2.1 \\
\hline DnaJ (Hsp40) homolog, subfamily C, member 3 & Dnajc3; hsp40 & U28423 & 2.3 & 2 \\
\hline FBJ osteosarcoma oncogene B & Fosb & $\mathrm{X} 14897$ & 2.3 & 2.1 \\
\hline RIKEN cDNA 2310005014 gene, mitochondrion & 2310005014Rik & AW124582 & 2.1 & 2.5 \\
\hline sphingosine-1-phosphate phosphatase 1 & Sgpp1 & Al835784 & 2 & 2 \\
\hline sialic acid acetylesterase; yolk sac gene 2 & Ysg2 & U61183 & 2 & 2.1 \\
\hline
\end{tabular}


Table 3-Transcriptional state of pluripotency genes following minimally toxic and acute exposures to $\mathrm{H}_{2} \mathrm{O}_{2}$.

\begin{tabular}{|l|l|l|}
\hline Description & Symbol & $\begin{array}{l}\text { Effect of OS dose on } \\
\text { Transcription }\end{array}$ \\
\hline Embryonic stem cell specific gene 1 & esg1 & No change \\
\hline Octamer binding transcription factor & oct3/4 & No change \\
\hline Zinc finger protein 42 & $\begin{array}{l}\text { zfp42 } \\
\text { (rex1) }\end{array}$ & No change \\
\hline Fibroblast growth factor 4 & fgf4 & No change \\
\hline SRY-box 2 & sox2 & No change \\
\hline Nanog homeobox & nanog & No change \\
\hline X-ray repair complementing 5 & xrcc5 & No change \\
\hline Radiation repair 23 homolog & rad23b & No change \\
\hline MutS homolog 2 (E. coli) & msh2 & No change \\
\hline Zinc finger protein 42 & zfp42 & No change \\
\hline Teratocarcinoma derived growth factor, CRIPT0 & tdgf1 & No change \\
\hline Integrin alpha 6 & itga6 & No change \\
\hline Signal transducer and activator of transcription 3 & stat3 & No change \\
\hline Multidrug resistance /ATP binding cassette & $\begin{array}{l}\text { Mdr1/ } \\
\text { abcb1 }\end{array}$ & $\begin{array}{l}2 x \text { up low dose } \\
\text { (2 isoforms) }\end{array}$ \\
\hline Excision repair complementing 5 & ercc5 & 2x up low dose \\
\hline Gastrulation Brain Homeobox 2 & gbx2 & $\begin{array}{l}10 x \text { down low dose; 3.4x } \\
\text { down high dose }\end{array}$ \\
\hline Forkhead homeobox D3 & foxod3 & $5 x$ down high dose \\
\hline Undifferentiated embryonic transcription factor & utf1 & $2 x$ down low dose \\
\hline myelocytomatosis viral oncogene homolog & c-myc & $\begin{array}{l}5.4 \text { down low dose; } \\
2.2 \text { down high dose }\end{array}$ \\
\hline
\end{tabular}


Table 4- Top significant functions and pathways affected by minimally toxic and acute exposures to $\mathrm{H}_{2} \mathrm{O}_{2}$.

\begin{tabular}{|c|c|c|}
\hline \multicolumn{3}{|l|}{ Low Dose Regulated Genes } \\
\hline Biological Function & \# transcripts & $p$-value ${ }^{a}$ \\
\hline $\begin{array}{l}\text { Tumorigenesis } \\
\text { Cell Death } \\
\text { Cellular Development } \\
\text { Gene Expression } \\
\text { Gastrointestinal Disease }\end{array}$ & $\begin{array}{l}139 \\
102 \\
81 \\
74 \\
55\end{array}$ & $\begin{array}{l}4.7 \times 10^{-9}-3.8 \times 10^{-2} \\
1.0 \times 10^{-4}-3.8 \times 10^{-2} \\
1.0 \times 10^{-6}-3.8 \times 10^{-2} \\
2.3 \times 10^{-5}-3.8 \times 10^{-2} \\
1.8 \times 10^{-5}-3.8 \times 10^{-2}\end{array}$ \\
\hline \multicolumn{3}{|l|}{ Canonical Pathway } \\
\hline $\begin{array}{l}\text { Wnt/L-Catenin Signaling } \\
\text { Biosynthesis of Steroids }\end{array}$ & $\begin{array}{l}11 \\
6\end{array}$ & $\begin{array}{l}7.1 \times 10^{-3} \\
7.5 \times 10^{-5}\end{array}$ \\
\hline \multicolumn{3}{|l|}{ High Dose Regulated Genes } \\
\hline Biological Function & \# transcripts & $p$-value \\
\hline $\begin{array}{l}\text { Tumorigenesis } \\
\text { Cellular Development } \\
\text { Cell Cycle } \\
\text { Embryonic Development } \\
\text { Respiratory Disease }\end{array}$ & $\begin{array}{l}49 \\
39 \\
36 \\
19 \\
7\end{array}$ & $\begin{array}{l}1.9 \times 10^{-4}-3.2 \times 10^{-2} \\
1.7 \times 10^{-5}-3.3 \times 10^{-2} \\
2.6 \times 10^{-5}-3.4 \times 10^{-2} \\
1.7 \times 10^{-5}-2.7 \times 10^{-2} \\
1.9 \times 10^{-4}-2.9 \times 10^{-2}\end{array}$ \\
\hline \multicolumn{3}{|l|}{ Canonical Pathway } \\
\hline $\begin{array}{l}\text { Coagulation system } \\
\text { VEGF Signaling } \\
\text { Riboflavin Metabolism } \\
\text { Cell Cycle: G1/S Checkpoint }\end{array}$ & $\begin{array}{l}6 \\
5 \\
4 \\
3\end{array}$ & $\begin{array}{l}2.2 \times 10^{-2} \\
4.9 \times 10^{-2} \\
1.8 \times 10^{-2} \\
3.9 \times 10^{-2}\end{array}$ \\
\hline \multicolumn{3}{|l|}{ Commonly Regulated Genes } \\
\hline Biological Function & \# transcripts & $p$-value \\
\hline $\begin{array}{l}\text { Tumorigenesis } \\
\text { Cellular Development } \\
\text { Neurological Development } \\
\text { Cell Cycle } \\
\text { Neurological Disease }\end{array}$ & $\begin{array}{l}13 \\
7 \\
7 \\
4 \\
2\end{array}$ & $\begin{array}{l}1.7 \times 10^{-5}-3.3 \times 10^{-2} \\
1.9 \times 10^{-5}-3.2 \times 10^{-2} \\
1.9 \times 10^{-5}-2.9 \times 10^{-2} \\
1.7 \times 10^{-5}-2.7 \times 10^{-2} \\
2.6 \times 10^{-5}-3.4 \times 10^{-2}\end{array}$ \\
\hline \multicolumn{3}{|l|}{ Canonical Pathway } \\
\hline $\begin{array}{l}\text { Coagulation } \\
\text { VEGF Signaling } \\
\text { Riboflavin Metabolism } \\
\text { Cell Cycle: G1/S Checkpoint }\end{array}$ & $\begin{array}{l}6 \\
5 \\
4 \\
3\end{array}$ & $\begin{array}{l}2.2 \times 10^{-2} \\
4.9 \times 10^{-2} \\
1.8 \times 10^{-2} \\
3.9 \times 10^{-2}\end{array}$ \\
\hline
\end{tabular}

aFisher's exact test 
Table 5-Phosphorylation alterations in response to minimally toxic and acute exposures to $\mathrm{H}_{2} \mathrm{O}_{2}$ and etoposide

\begin{tabular}{|c|c|c|c|c|c|}
\hline \multicolumn{6}{|c|}{ Phosphorylation detected in control and significantly altered following stress. } \\
\hline \multirow[b]{2}{*}{ Mouse (epitope) } & \multirow[b]{2}{*}{ Human (epitope) } & \multirow[b]{2}{*}{ Controla $^{a}$} & \multicolumn{3}{|c|}{ fold phos. relative to control } \\
\hline & & & Etoposide & $100 \mu \mathrm{M}$ & $5 \mathrm{mM}$ \\
\hline INSR (Y972) & INSR (Y972) & 500 & 1 & 0.45 & 1 \\
\hline PKN1 (PRK1) (T778) & PRK1 (T774) & 435 & 1 & 0.6 & 1 \\
\hline PRKCD (T505) & Prkcd (T505) & 544 & 0.6 & 0.6 & 1 \\
\hline RAF1 (S259) (60 kD) & RAF1 (S259) & 471 & 1 & 0.6 & 1 \\
\hline PKN2 (N/A) & PRK2 (T816) & 397 & 0.7 & 0.6 & 1 \\
\hline PPP1CA (T320) & PP1a (T320) & 422 & 0.56 & 0.61 & 0.5 \\
\hline RAF1 (S259) (70 kD) & RAF1 (S259) & 999 & 1 & 0.63 & 0.68 \\
\hline MAP2K1 (T292) & MEK1 (T291) & 1700 & 0.75 & 0.67 & 0.49 \\
\hline MAP2K1 (T386) & MEK1 (T385) & 475 & 1 & 1 & 0 \\
\hline RB1 $(\mathrm{S} 773)^{b}$ & Rb1 (S780) & 296 & 1 & 1 & 0 \\
\hline SRC (Y423) & SRC (Y418) & 400 & 0.33 & 1 & 0.17 \\
\hline PTK2 (S722) & FAK (S722) & 700 & 1 & 1 & 0.27 \\
\hline PRKCZ (T410/T402) & Prkcz/l(T410/T403) & 498 & 1 & 1 & 0.6 \\
\hline SRC (Y534) & SRC (Y529) & 2800 & 1 & 1 & 1.3 \\
\hline MAP2K1 (S298) & MEK1 (S297) & 400 & 1 & 1 & 1.5 \\
\hline CDC2 (Y15) & CDK1 (Y15) & 2530 & 1 & 1 & 1.6 \\
\hline $\begin{array}{l}\text { MAPK8(JNK/SAPK) } \\
\text { (T183/Y185) (47 kD) }\end{array}$ & JNK (SAPK) (T183/Y185) & 800 & 0.7 & 1 & 1 \\
\hline PTK2 (S910) & FAK (S910) & 700 & 0.47 & 1.25 & 1 \\
\hline NPM1 (S4) & NPM1 (S4) & 2719 & 1 & 1.3 & 1 \\
\hline PRKCM (S916) & Prkcm (S910) & 305 & 1 & 1.3 & 1.3 \\
\hline AKT1 (S473) & PKBa (Akt1)(S473) & 400 & 0.65 & 1.3 & 3.76 \\
\hline EIF2B5 (S539) & elF2Be (S540) & 300 & 1.43 & 1.34 & 1.48 \\
\hline CDC2 (T161/T160) & CDK1 (T161/T160) & 386 & 1.65 & 1.74 & 2.6 \\
\hline MAPK14 (T180+Y182) & p38aMAPK (T180/Y182) & 450 & 3.92 & 1.9 & 3.66 \\
\hline \multicolumn{6}{|c|}{ Phosphorylation detected in control and not altered following stress. } \\
\hline & & & \multicolumn{3}{|c|}{ fold phos. relative to control } \\
\hline LYN (Y507) (50kD) & Lyn (Y507) (50kD) & 721 & 1 & 1 & 1 \\
\hline LYN (Y507) (47kD) & Lyn (Y507) (47kD) & 895 & 1 & 1 & 1 \\
\hline PDPK1 (S241) & PDK1 (S244) & 1066 & 1 & 1 & 1 \\
\hline MAP2K6 (S207) & MKK6 (S207) & 1306 & 1 & 1 & 1 \\
\hline CDC2 (T14+Y15) & CDK1 (T14/Y15) & 3500 & 1 & 1 & 1 \\
\hline \multicolumn{6}{|c|}{$\begin{array}{c}\text { Phosphorylation below } 300 \text { (normalized intensities) in control and } \\
\text { significantly altered to near } 300 \text { following stress. }\end{array}$} \\
\hline & & \multicolumn{4}{|c|}{ normalized intensities } \\
\hline MAPK1(T185+Y187) & ERK2 (T185/Y187) & 36 & 52 & 53 & 376 \\
\hline MAP2K1(S217/S221) & MEK1 (S217/S221) & 91 & 104 & 175 & 380 \\
\hline AKT1 (T308) & PKBa/Akt1 (T308) & 99 & 64 & 49 & 296 \\
\hline GSK3a (S21) & GSK3a (S21) & 144 & 255 & 206 & 166 \\
\hline
\end{tabular}

a Green shading in control column indicates that the normal effect of protein phosphorylation is activation. Red shading in control indicates that the normal effect of protein phosphorylation is inhibition.

b PRKCZ was significantly up-regulated following $5 \mathrm{mM} \mathrm{H}_{2} \mathrm{O}_{2}$ in parallel transcriptional microarray analysis.

c $\mathrm{Rb} 1$ was significantly down-regulated following $5 \mathrm{mM} \mathrm{H}_{2} \mathrm{O}_{2}$ in parallel transcriptional microarray analysis. 


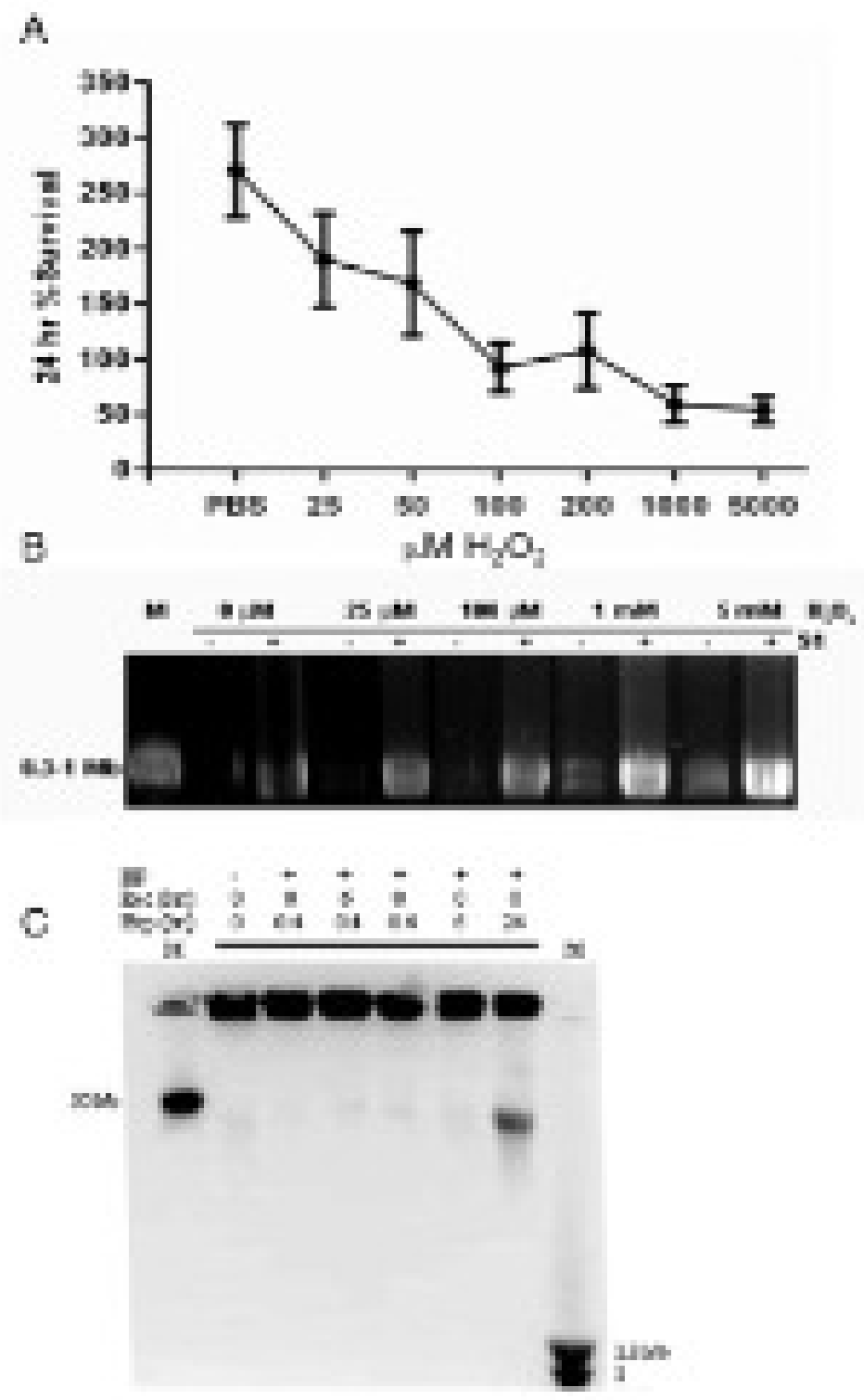

Fig. 1- Response of ES cells in culture 24 hrs following exposure to minimally toxic ROS. A. Cells were exposed to $\mathrm{H}_{2} \mathrm{O}_{2}$ for $15 \mathrm{~min}$, recovered in normal medium for $20 \mathrm{hrs}$, then the number of viable cells in culture scored (dead cells were excluded by trypan blue). Data are the average and standard deviation of at least 4 independent experiments. B. Dose-dependent accumulation of single-strand breaks (SSBs) following exposure to $\mathrm{H}_{2} \mathrm{O}_{2}$ for 15 min. Pulse field gel electrophoresis of agarose embedded DNA without (-; DSB) or with (+; SSB and DSB) S1 nuclease digestion. DNA fragmentation was not evident in samples exposed to $\mathrm{H}_{2} \mathrm{O}_{2}$ at lower doses. Fragmentation was observed at higher doses ( $1 \mathrm{mM}$ and $5 \mathrm{mM})$. As expected, visible fragmentation was detected in all samples, including untreated, following $S 1$ nuclease digestion. Visible fragments were within the $0.3-1 \mathrm{Mb}$ range. C. Time-dependent accumulation of $50 \mathrm{~kb}$ fragments following exposure (Exp) to $100 \mathrm{IM} \mathrm{H} \mathrm{H}_{2} \mathrm{O}_{2}$ with or without recovery (Rec). $50 \mathrm{~kb}$ fragments observed only after chronic 24 hour continuous exposure and no recovery. $\mathrm{M}$-- size standard marker. 


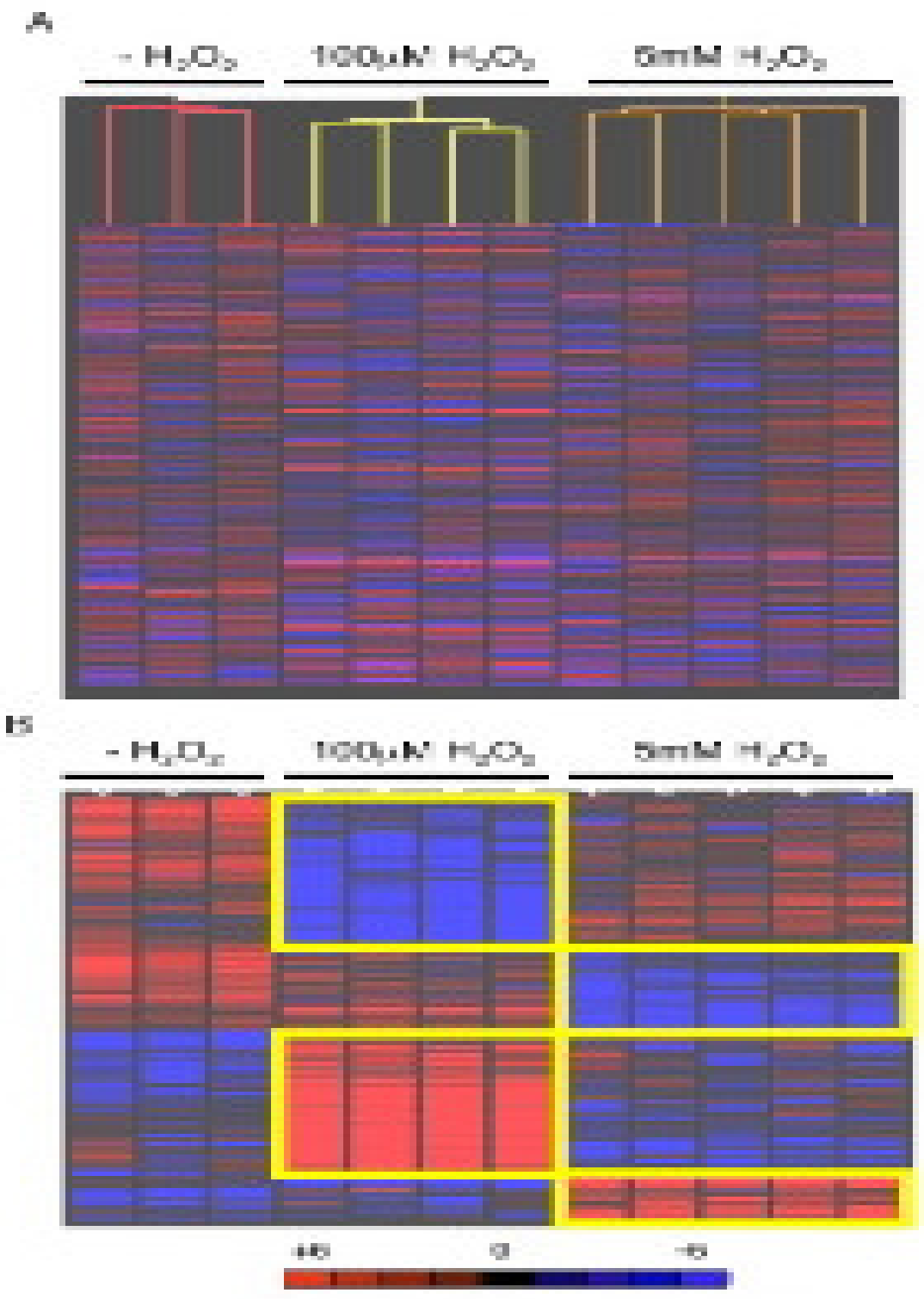

Fig. 2- A. Relatedness of sample groups confirmed by unsupervised Pearson correlation clustering of transcripts deregulated by two-fold between controls and replicate samples. Analysis performed by GeneSpring data analysis software. B. Distinct gene expression signatures induced by low and high doses of $\mathrm{H}_{2} \mathrm{O}_{2}$. Parametric t-test with unequal variance (Welch t-test) analysis was performed by GeneSpring data analysis software. 
A

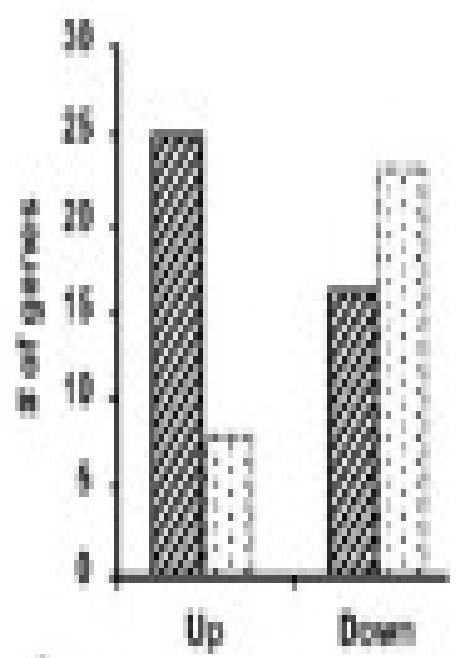

C

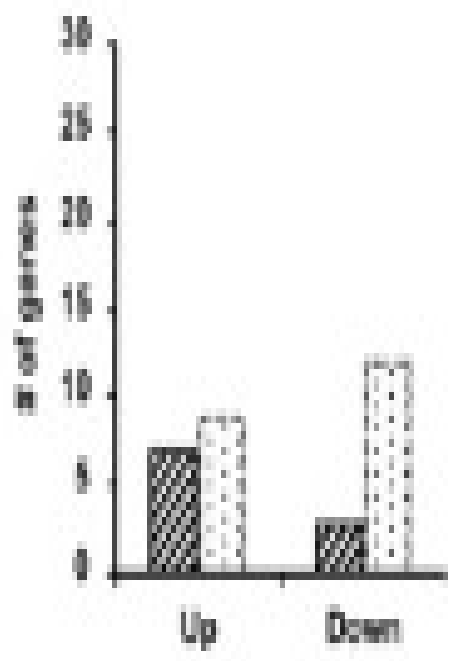

$\mathrm{B}$
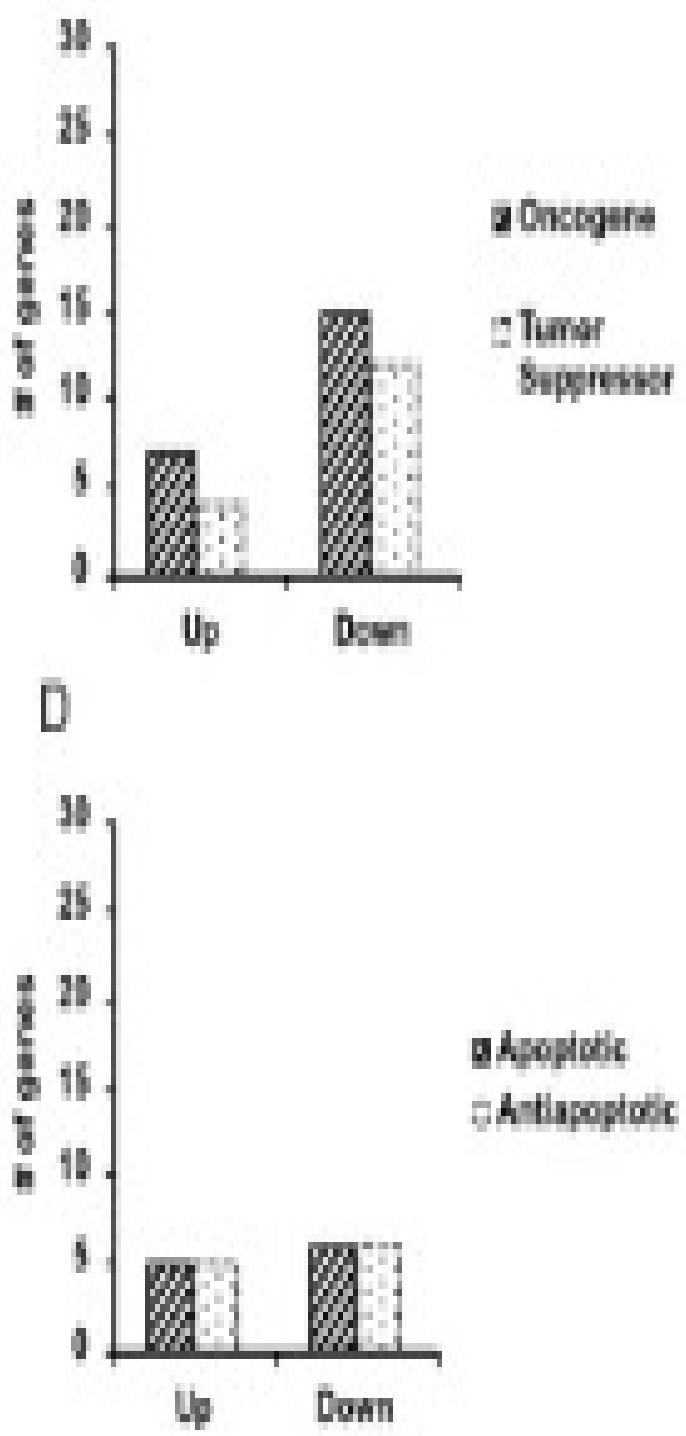

Fig. 3-IPA clustering shows distinct response of ES cells to minimally toxic ROS. IPA clustering was performed on

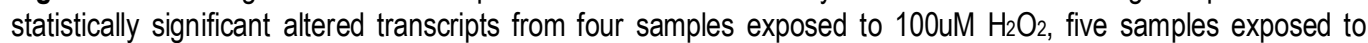
$5 \mathrm{mM} \mathrm{H} \mathrm{O}_{2}$, and three replicate control samples analyzed by Affymetrix MG-U74VerA chips and GeneSpring software. A. Altered oncogene and tumor suppressor transcripts following $100 \mathrm{M} \mathrm{H}_{2} \mathrm{O}_{2}$. B. Altered oncogene and tumor suppressor transcripts following $5 \mathrm{mM} \mathrm{H}_{2} \mathrm{O}_{2}$. C. Altered apoptotic and anti-apoptotic transcripts following $100 \mathrm{M} \mathrm{H}_{2} \mathrm{O}_{2}$. D. Altered apoptotic and anti-apoptotic transcripts following $5 \mathrm{mM} \mathrm{H}_{2} \mathrm{O}_{2}$. 